\title{
STABILIZATION OF IKPAYONGO LATERITE WITH CEMENT AND CALCIUM CARBIDE WASTE
}

\section{MANASSEH JOEL AND E. JOSEPH EDEH}

(Received 25 July 2013; Revision Accepted 9 June 2014)

\begin{abstract}
Laterite obtained from Ikpayongo was stabilized with 2-10\% cement and 2-10\% Calcium Carbide waste, for use as pavement material. Atterberg's limits test, California bearing ratio (CBR) and unconfined compressive strength (UCS) tests were conducted on the natural laterite and the treated soil specimens. The plasticity index of the natural laterite reduced from $14 \%$ to a minimum value of $5 \%$ when treated with a mixture of $10 \%$ cement plus $10 \%$ calcium carbide waste, strength indices of the laterite was greatly improved as the 7 day UCS and CBR values of Ikpayongo laterite increased from $534 \mathrm{kN} / \mathrm{m}^{2}$ and $28 \%$ respectively to $3157 \mathrm{kN} / \mathrm{m}^{2}$ and $180 \%$ respectively, when treated with a combination of $10 \%$ cement plus $10 \%$ calcium carbide waste. Based on results obtained from the study, the use of a mixture of $8 \%$ cement plus $10 \%$ calcium carbide waste, $10 \%$ cement plus $10 \%$ calcium carbide waste are recommended for the treatment of Ikpayongo laterite for use as base material. The use of calcium carbide waste in the stabilization of soil will ensure economy in road construction, while providing an effective way of disposing calcium carbide waste.
\end{abstract}

KEYWORDS: Cement, Calcium carbide waste, Stabilization, Ikpayongo laterite, Pavement material.

\section{INTRODUCTION}

Road building in the developing nations has been a major challenge to Government and different specialists in the construction industry. The challenge facing Government is the limited resources available for the construction of roads and the high cost of road building normally put forward by the construction companies. On road construction site, the contractor is faced with the problem of non availability of suitable road construction materials, within the vicinity of most road projects. A situation that normally results in the usage of materials imported from other locations, resulting in additional costs that does not guarantee economy in road construction. One of the ways of ensuring economy is making suitable for road work locally available materials within the vicinity of road projects, through stabilization. One of such materials that is readily available in Nigeria is laterite.

Laterite as defined by Osula (1993) is a highly weathered tropical soil, rich in secondary oxide of any or a combination of iron, aluminium and manganese. Lateritic soils according to Bello \& Adegoke (2010) can be categorized into laterite, lateritic, and non-lateritic soils, but stressed that such definition may not be convenient from an engineering point of view, especially where there is lack of adequate laboratory facilities, because mode of differentiation is based on the silica $\left(\mathrm{SiO}_{2}\right)$ to sesquioxide ratios $\left(\mathrm{Fe}_{2} \mathrm{O}_{3}, \mathrm{Al}_{2} \mathrm{O}_{3}\right)$, less than 1.33 are indicative of laterites, those between 1.33 and 2.00 show laterite and those greater than 2.00 of nonlateritic types (Bell, 1993). The definition of laterite by Ola (1983), as the products of tropical weathering with red, reddish brown, and dark brown colour, with or without nodules or concretions and generally (but not exclusively) found below hardened ferruginous crust or hard pan, will be adopted in this study.

Laterite soils according to Bello (2010) are formed in hot, wet tropical regions with an annual rainfall between $750 \mathrm{~mm}$ to $3000 \mathrm{~mm}$ (usually in area with a significant dry season) on a variety of different types of rocks with high iron content. Laterite according to Ford (1989) is found mainly, but not exclusively, as a residual weathering product on partially or wholly decomposed basalts and other basic to intermediate igneous rocks. Occurrences are locally extensive, but in general have not been mapped, although some studies made on material from specific localities have proved that they are good material for road work.

Nigeria according to Umar \& Elinwa (2005) is among the countries blessed with vast deposits of laterite, which is residual in nature, and one of the cheapest material for road construction. However, not all deposits of laterite are suitable for use as base and subbase material in their natural state. Treatment with additives is normally required before such laterite can attain the desired properties.

Lime and cement have been meaningfully used for soil stabilization and improvement (Reids \& Brooks, 1999, Basha, Hashim, Mahmud, \& Muntohar.,2005, Eze-Uzomaka \& Agbo, 2010, Joel \& Agbede, 2011, Joel \& Agbede, 2010). Improvement in properties of soil treated with cement is attributed to the hydration reaction of cement, while that of lime can be attributed to the cation exchange, pozzolanic and carbonation reactions of lime. The use of cement for soil stabilization

Manasseh Joel, Department of Civil Engineering, University of Agriculture P.M.B 2373, Makurdi Benue state, Nigeria.

E. Joseph Edeh, Department of Civil Engineering, University of Agriculture P.M.B 2373, Makurdi Benue state, Nigeria. 
is very effective when the plasticity index is less than 10 $\%$.According to (Garba \& Hoel, 2010, Yoder \& Witczak, 1975 ) where plasticity index value is greater than $10 \%$ more cement will be required for effective stabilization. An alternative to the use of high percentage of cement is the use of lime as a modifier to reduce the plasticity index of the soil before the use of cement for stabilization. In Makurdi, the capital of Benue State, Nigeria, West Africa, a $25 \mathrm{Kg}$ bag of hydrated lime or quick lime is sold at 5,000 , respectively, while the cost of $50 \mathrm{~kg}$ bag of cement is sold at $\mathbb{N}, 800$ an indication that the cost of hydrated lime is 5.56 times the equivalent cost of ordinary Portland cement. The exorbitant costs of lime have hindered adequate soil stabilization to meet the standard recommended for road construction.

In order to reduce the cost of stabilization of materials for road construction, one reasonable alternative is the use of wastes. Researchers have shown that utilization of wastes has resulted in considerable savings in construction costs as well as improvement in soil properties. (Umar \& Elinwa, 2005, Umar \& Osinubi, 2003, Okafor \& Okonkwo, 2009). Calcium carbide waste used in this study is at little or no cost, as it is normally disposed off on land. Calcium carbide waste is a by-product recovered from the production of acetylene gas $\left(\mathrm{C}_{2} \mathrm{H}_{2}\right)$ used in oxyacetylene welding. It consists mainly of $\left(\mathrm{Ca}(\mathrm{OH})_{2}\right)$ lime, caustic solid substances, and white in appearance when pure. Calcium carbide waste is normally dumped at different locations, especially mechanic villages and industries where oxy-acetylene gas welding is carried out. Such sites and locations are common features in most urban centres and some rural areas, in Nigeria. Calcium carbide waste is normally disposed via land fill or open dumping which have effect on surface and ground water, arising from the leaching of harmful compounds and alkali to ground and surface water. Therefore, alternative means of disposal are desirable. Utilization of the waste material to upgrade the engineering properties of laterite would serve as one of the disposal outlets. The effective utilization of calcium carbide waste in soil stabilization was reported by (Somna, Jaturapitakkul, \& Kajitvichyanukul, 2011, Horpibulsuk, phetchuay \& chinkulkijniwat, 2012, and Du, Zhang, \& Liu, 2011). The aim of this study is to treat Ikpayongo laterite with a combination of cement and calcium carbide waste in order to improve its properties and ascertain its suitability for use as pavement material.

\section{MATERIALS AND METHODS}

Laterite sample was collected from Ikpayongo, located at a distance of 22 kilometres from Makurdi, the capital of Benue State, Nigeria, along Makurdi- Otukpo road. The borrow pit was located at a distance of $50 \mathrm{~m}$ and at an angle of $90^{\circ}$ East from the centre line of the road. Disturbed samples were collected at a depth of 0.5 to $2.0 \mathrm{~m}$ after the removal of the top soil. Calcium carbide waste was collected from a welder located at the North bank mechanic village in Makurdi. It was dried in the open air, and grinded into fine particles, using pestle and motar (in the absence of a ball mill and made to pass through the $300 \mu \mathrm{m}$ B.S sieve). Ordinary Portland cement as obtained from the open market in Makurdi was used for the work. Chemical analysis of calcium carbide waste and ordinary porland cement was carried out using $\mathrm{x}$-ray analyzer together with Atomic Absorption Spectrophotometer (AAS).

Laboratory tests were performed on the sample obtained from Ikpayongo in accordance with BS1377 (1990) for the natural laterie and BS1924 (1990) for the stabilized laterite. California bearing ratio (CBR) tests were conducted in accordance with the Nigerian code which stipulated that specimens be cured in the dry for six days then soaked for 24 hours before testing. Tests performed on Ikpayongo laterite sample mixed with cement and calcium carbide waste include, Atterberg's limits tests, compaction tests, Unconfined Compressive strength (UCS) tests and California bearing ratio tests.

Compaction was carried out using the West African standard compactive effort, because it was the conventional energy level commonly used in the region and recommended by the Nigerian code. The resistance to loss in strength was determined as a ratio of the unconfined compressive strength (UCS) of specimens cured for 7 days under controlled conditions, which were subsequently immersed in water for another 7 days to the UCS of specimens cured for 14 days. The particle size distribution of the laterite was determined using the wet sieving method.

\section{RESULTS AND DISCUSSION}

The grain size distribution curve of Ikpayongo laterite is as presented in Figure 1, the chemical analysis of ordinary Portland cement and calcium carbide waste is as summarized in Table 1. Summary of the results of tests on the natural laterite is as presented in Table 2. 


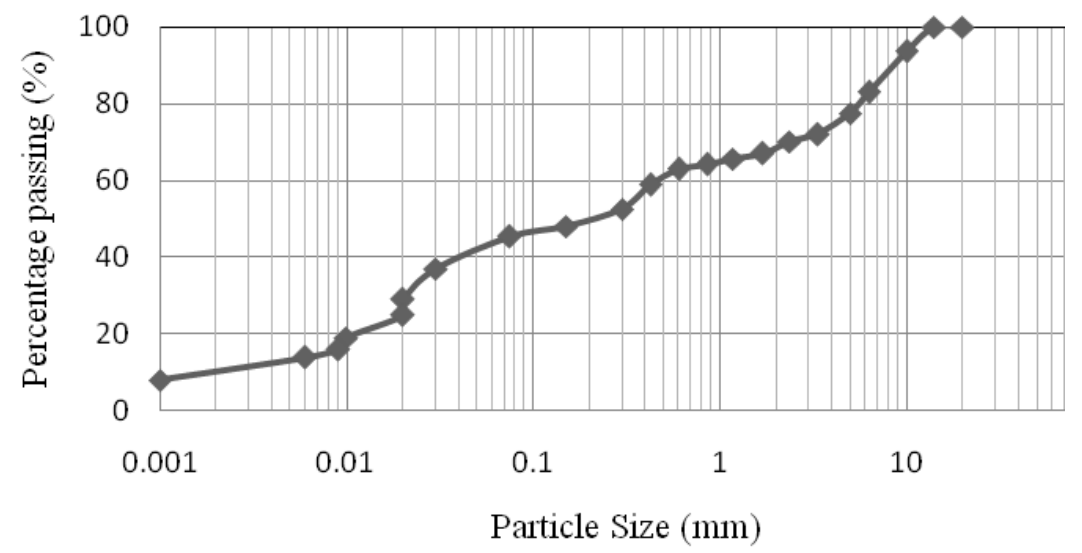

Figure 1: Particle size distribution of Ikpayongo Laterite.

Table 1: Chemical Composition of Calcium Carbide Waste and Cement.

\begin{tabular}{|l|l|l|}
\hline \multirow{2}{*}{ Elemental Oxide } & Percentage Composition $(\%)$ \\
\cline { 2 - 3 } & Calcium carbide waste & Cement \\
\hline $\mathrm{CaO}$ & 61.41 & 64 \\
\hline $\mathrm{MgO}$ & 0.80 & 1.94 \\
\hline $\mathrm{Al}_{2} \mathrm{O}_{3}$ & 1.78 & 5.75 \\
\hline $\mathrm{Fe}_{2} \mathrm{O}_{3}$ & 0.17 & 2.50 \\
\hline $\mathrm{SiO}_{2}$ & 2.69 & 20.40 \\
\hline $\mathrm{SO}_{3}$ & 0.36 & 2.75 \\
\hline $\mathrm{LOI}$ & 32.51 & 1.20 \\
\hline
\end{tabular}

LOI: Loss on Ignition.

Table 2: Some Geotechnical Properties of Ikpayongo Laterite.

\begin{tabular}{|l|l|}
\hline PROPERTY & QUANTITY \\
\hline Percentage Passing BS Sieve No 200 (\%) & 45.5 \\
\hline Liquid Limit, (\%) & 33 \\
\hline Plastic Limit (\%) & 19 \\
\hline Plasticity Index (\%) & 14 \\
\hline AASHTO Classification & A-2-6 \\
\hline USCS Classification & $\mathrm{GP}$ \\
\hline Maximum Dry Density,Mg/m ${ }^{3}$ & 1.86 \\
\hline Optimum Moisture Content (\%) & 12 \\
\hline Unconfined Compressive Strength $\mathrm{kN} / \mathrm{m}^{2}$ & 534 \\
\hline California Bearing Ratio,\% (after 24hrs soaking) & 28 \\
\hline Specific Gravity & 2.69 \\
\hline Colour & Reddish brown \\
\hline Natural Moisture Content (\%) & 6.90 \\
\hline
\end{tabular}

Ikpayongo laterite was found to be an A-2-6 and GP soil by the AASHTO and unified soil classification systems respectively. The specific gravities of Ikpayongo laterite, calcium carbide waste and cement were determined as $2.69,1.90$, and 3.15 respectively. The geotechnical properties of Ikpayongo laterite clearly shows that it is only suitable for use as fill material and not sub-base and base material based on the Nigerian General Specification for road and bridges (1997), hence the need for stabilization to make it suitable for use as sub-base and base material.

The addition of both cement and calcium carbide waste to Ikpayongo laterite improves its consistency indices, as the plasticity index reduced from $14 \%$ to $5 \%$ when treated with a combination of $10 \%$ cement plus $10 \%$ calcium carbide waste. Variation of liquid limit, plastic limit and plasticity index of Ikpayongo laterite with cement and calcium carbide waste content is as presented in Table 3. 
Table 3: Atterberg's Limits of Ikpayongo Laterite Treated with Calcium Carbide Waste and Cement.

\begin{tabular}{|c|c|c|c|c|c|c|c|}
\hline \multicolumn{2}{|c|}{ Cement Content (\%) } & 0 & 2 & 4 & 6 & 8 & 10 \\
\hline \multirow[t]{3}{*}{$0 \% \mathrm{CCW}$} & $\mathrm{LL}$ & 33 & 31 & 29 & 26 & 24 & 22 \\
\hline & $\mathrm{PL}$ & 19 & 18 & 17 & 15 & 14 & 13 \\
\hline & $\mathrm{PI}$ & 14 & 13 & 12 & 11 & 10 & 9 \\
\hline \multirow{3}{*}{$2 \%$ CCW } & LL & 34 & 32 & 30 & 27 & 26 & 23 \\
\hline & $\mathrm{PL}$ & 21 & 20 & 19 & 17 & 17 & 15 \\
\hline & $\mathrm{PI}$ & 13 & 12 & 11 & 10 & 9 & 8 \\
\hline \multirow[t]{3}{*}{$4 \% \mathrm{CCW}$} & LL & 36 & 33 & 30 & 28 & 26 & 24 \\
\hline & $\mathrm{PL}$ & 24 & 22 & 20 & 18 & 18 & 17 \\
\hline & $\mathrm{PI}$ & 12 & 11 & 10 & 10 & 8 & 7 \\
\hline \multirow[t]{3}{*}{$6 \% \mathrm{CCW}$} & LL & 38 & 36 & 32 & 29 & 28 & 27 \\
\hline & $\mathrm{PL}$ & 27 & 26 & 23 & 21 & 21 & 21 \\
\hline & $\mathrm{PI}$ & 11 & 10 & 9 & 8 & 7 & 6 \\
\hline \multirow[t]{3}{*}{$8 \% \mathrm{CCW}$} & LL & 40 & 38 & 35 & 32 & 31 & 29 \\
\hline & $\mathrm{PL}$ & 30 & 29 & 27 & 25 & 25 & 24 \\
\hline & $\mathrm{PI}$ & 10 & 9 & 8 & 7 & 6 & 5 \\
\hline \multirow[t]{3}{*}{$10 \% \mathrm{CCW}$} & LL & 41 & 39 & 37 & 34 & 33 & 30 \\
\hline & $\mathrm{PL}$ & 32 & 31 & 30 & 28 & 27 & 25 \\
\hline & $\mathrm{PI}$ & 9 & 8 & 7 & 6 & 6 & 5 \\
\hline
\end{tabular}

LL= Liquid Limit (\%), PL = Plastic Limit, (\%), PI = Plasticity Index, (\%). CCW= Calcium Carbide Waste.

The variation of maximum dry density and optimum moisture content of Ikpayongo laterite with cement and calcium carbide waste content is as presented in Figures 2 and 3 respectively. The addition of either cement or calcium carbide waste and their combinations to Ikpayongo laterite resulted in increased maximum dry density, due to a decrease in the surface area of the clay fraction of Ikpayongo laterite arising from the substitution of Ikpayongo laterite with cement and calcium carbide waste. The maximum dry density of the untreated laterite increased from $1.86 \mathrm{Mg} / \mathrm{m}^{3}$ to 2.09 $\mathrm{Mg} / \mathrm{m}^{3}$ when treated with a mixture of $10 \%$ cement plus $10 \%$ calcium carbide waste, while the optimum moisture content of Ikpayongo laterite increased

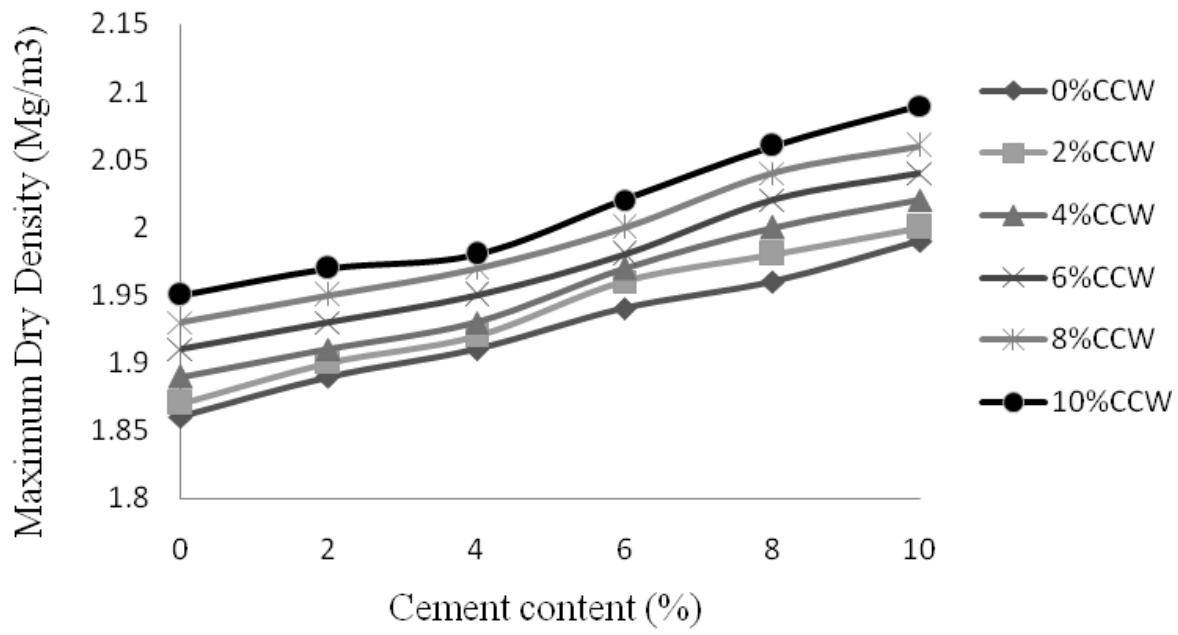

Figure 2: Variation of Maximum Dry Density with cement and calcium carbide waste (CCW) content $(\%)$ 


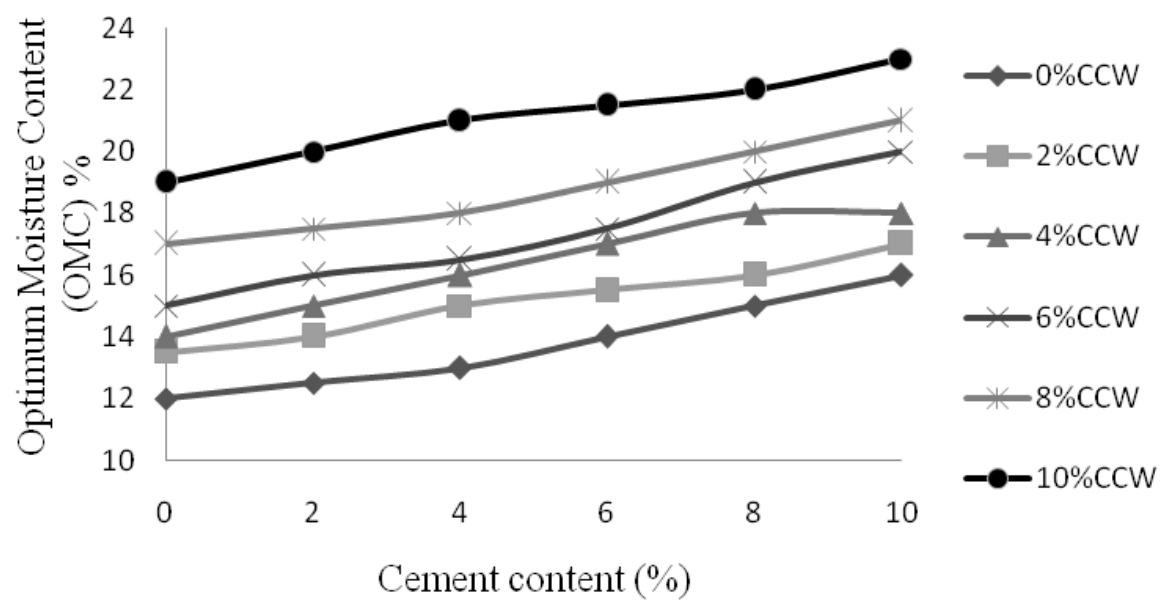

Figure 3: Variation of Optimum Moisture Content (OMC) with cement and calcium carbide waste (CCW) content

$(\%)$

From $12 \%$ to $23 \%$ when treated with a combination of $10 \%$ cement plus $10 \%$ calcium carbide waste. The increase in optimum moisture content can be attributed to more moisture required for effective hydration of cement and the pozzolanic reaction of calcium carbide waste.

The results of strength indices and durability tests carried out on Ikpayongo laterite calcium carbide waste and cement mixture is as presented in Table 4. Seven (7) day UCS value of Ikpayongo laterite increased from $534 \mathrm{kN} / \mathrm{m}^{2}$ to $1255 \mathrm{kN} / \mathrm{m}^{2}$ when treated with $10 \%$ cement, and $1193 \mathrm{kN} / \mathrm{m}^{2}$ when treated with $10 \%$ calcium carbide waste. Treatment with cement and calcium carbide waste mixtures exhibited increase in strength with cement and calcium carbide waste content used, with the attainment of maximum 7 day UCS value of $3157 \mathrm{kN} / \mathrm{m}^{2}$, when Ikpayongo laterite was treated with a combination of $10 \%$ cement plus $10 \%$ calcium carbide waste.

The use of only cement or calcium carbide waste did not satisfy the minimum resistance to loss of strength value of $20 \%$, specified by Ola (1974). The use of cement-calcium carbide waste mixture improved the resistance to loss of strength of Ikpayongo laterite with the attainment of maximum resistance to loss of strength value of $91.7 \%$ at a combination of $10 \%$ cement plus $10 \%$ calcium carbide waste. California bearing ratio (CBR) value of Ikpayongo laterite increased from $28 \%$ to $85 \%$ when treated with $10 \%$ calcium carbide waste, and $135 \%$ when treated with $10 \%$ cement.

The use of a combination of cement and calcium carbide waste exhibited a maximum CBR value of $180 \%$ when Ikpayongo laterite was treated with a combination of $10 \%$ cement plus $10 \%$ calcium carbide waste. The satisfaction of minimum 7 day UCS value of $1720 \mathrm{kN} / \mathrm{m}^{2}$ specified by Millard (1993), CBR value of $180 \%$ and $160 \%$ using the mix in place method and plant mix method, respectively, specified by the Nigerian code and durability requirement specified by Ola (1974), when Ikpayongo laterite was treated with some of the combinations is an indication that treated Ikpayongo laterite can be used for road work. 
Table 4: Durability and Strength Indices Result of Ikpayongo Laterite Stabilized with Cement and Calcium Carbide Waste.

\begin{tabular}{|c|c|c|c|c|c|c|c|}
\hline \multicolumn{2}{|c|}{ Cement Content (\%) } & 0 & 2 & 4 & 6 & 8 & 10 \\
\hline \multirow{5}{*}{$0 \% \mathrm{CCW}$} & CBR(\%) & 28 & 70 & 90 & 100 & 120 & 135 \\
\hline & 7dUCS & 534 & 606 & 723 & 872 & 1044 & 1255 \\
\hline & 14dUCS & 534 & 733 & 879 & 1059 & 1268 & 1518 \\
\hline & 28dUCS & 534 & 861 & 1034 & 1240 & 1492 & 1788 \\
\hline & $\mathrm{R}(\%)$ & 0 & 40.74 & 44.22 & 60.89 & 70.35 & 78.00 \\
\hline \multirow[t]{5}{*}{$2 \% \mathrm{CCW}$} & CBR(\%) & 50 & 80 & 90 & 110 & 130 & 145 \\
\hline & 7dUCS & 570 & 726 & 873 & 1045 & 1252 & 1505 \\
\hline & 14dUCS & 690 & 873 & 1059 & 1259 & 1523 & 1848 \\
\hline & 28dUCS & 774 & 1020 & 1228 & 1473 & 1763 & 2119 \\
\hline & $\mathrm{R}(\%)$ & 23.9 & 46.31 & 50.57 & 73.58 & 77.47 & 81.76 \\
\hline \multirow[t]{5}{*}{$4 \% \mathrm{CCW}$} & CBR(\%) & 60 & 90 & 100 & 120 & 135 & 150 \\
\hline & 7dUCS & 683 & 879 & 1053 & 1262 & 1515 & 1817 \\
\hline & 14dUCS & 789 & 1056 & 1270 & 1522 & 1824 & 2188 \\
\hline & 28dUCS & 891 & 1249 & 1489 & 1769 & 2163 & 2505 \\
\hline & $R(\%)$ & 34 & 50.84 & 57.35 & 75.19 & 79.73 & 83.61 \\
\hline \multirow[t]{5}{*}{$6 \%$ CCW } & $\mathrm{CBR}(\%)$ & 70 & 100 & 110 & 130 & 140 & 160 \\
\hline & 7dUCS & 781 & 1048 & 1254 & 1506 & 1805 & 2165 \\
\hline & 14dUCS & 804 & 1248 & 1499 & 1794 & 2152 & 2586 \\
\hline & 28dUCS & 925 & 1493 & 1788 & 2146 & 2577 & 3092 \\
\hline & $\mathrm{R}(\%)$ & 43.87 & 54.85 & 60.24 & 78.33 & 82.22 & 86.32 \\
\hline \multirow[t]{5}{*}{$8 \%$ CCW } & CBR(\%) & 80 & 110 & 120 & 140 & 150 & 170 \\
\hline & 7dUCS & 887 & 1217 & 1463 & 1756 & 2107 & 2528 \\
\hline & 14dUCS & 943 & 1502 & 1805 & 2165 & 2600 & 3121 \\
\hline & 28dUCS & 1014 & 1770 & 2123 & 2550 & 3058 & 3666 \\
\hline & $\mathrm{R}(\%)$ & 52.78 & 60.08 & 62.74 & 81.69 & 85.65 & 89.13 \\
\hline \multirow[t]{5}{*}{$10 \%$ CCW } & CBR(\%) & 85 & 120 & 130 & 150 & 170 & 180 \\
\hline & 7dUCS & 867 & 1475 & 1782 & 2155 & 2611 & 3157 \\
\hline & 14dUCS & 1035 & 1812 & 2176 & 2612 & 3135 & 3761 \\
\hline & 28dUCS & 1193 & 2101 & 2517 & 3022 & 3623 & 3852 \\
\hline & $\mathrm{R}(\%)$ & 60.23 & 64.45 & 67.58 & 85.02 & 88.13 & 91.71 \\
\hline
\end{tabular}

CBR = California Bearing Ratio (\%) , R = Resistance to loss in Strength, (\%). $\mathrm{CCW}=$ Calcium Carbide Waste,

7 dUCS $=$ Seven day Unconfined Compressive Strength, $\mathrm{kN} / \mathrm{m}^{2}$

14 dUCS = Fourteen day Unconfined Compressive strength, $\mathrm{kN} / \mathrm{m}^{2}$ 28 dUCS $=$ Twenty eight day Unconfined Compressive strength, $\mathrm{kN} / \mathrm{m}^{2}$

Ikpayongo laterite treated with a combination of $8 \%$ cement plus $10 \%$ calcium carbide waste using the plant mix method and $10 \%$ cement plus $10 \%$ calcium carbide waste using the mix in place method are recommended for use as base material. The use of Ikpayongo laterite treated with a combination of $6 \%$ cement plus $8 \%$ calcium carbide waste is recommended for use as sub-base material.

\section{CONCLUSIONS}

Based on this study, the following conclusions can be drawn:

1. The plasticity index of Ikpayongo laterite decreased from $14 \%$ to $5 \%$, when treated with10 \% cement plus $10 \%$ calcium carbide waste.

2. Ikpayongo laterite treated with a combination of $6 \%$ cement plus $8 \%$ calcium carbide waste is recommended for use as sub-base material in pavement work.
3. Ikpayongo laterite treated with a combination of $8 \%$ cement plus $10 \%$ calcium carbide waste is recommended for use as base material in pavement work.

\section{REFERENCES}

British Standards (BS)., 1377. 1990. Methods of Testing Soils for Civil Engineering Purposes. British Standards Institution: London, Uk.

British standards (BS)., 1990. Methods of Test for Stabilized Soils. British Standards Institution: London, Uk

Bello, A. A and Adegoke, C. W., 2010. "Evaluation of Geotechnical Properties of Ilesha East South West Nigeria's lateritic Soil." Pacific Journal of Science and Technology. 11, (2): 617-624. 
Bell, F. G., 1993. Engineering Geology. Blackwell Scientific: London, Uk.

Basha, E. A., Hashim, R., Mahmud, H. B and Muntohar, A. S., 2005. "Stabilization of residual soil with rice husk ash and cement". Construction and Building Materials, 19, 448-453.

Zhang, Du, Y., Y and Liu, S., 2011. "Investigation of Strength and California Bearing Ratio properties of Natural Soils Treated by Calcium Carbide Residue". Geo-Frontiers: 1237-1244.

Eze-Uzomaka, O. J and Agbo, D., 2010. "Suitability of quarry dust as improvement to cement Stabilized-laterite for road bases". Electronic journal of Geotechnical Engineering_15, (k); 1053-1066.

Ford, O. S., 1989. "The economic mineral resources of the Benue trough", In: C.A. Kogbe, (ed.), Geology of Nigeria, (pp 473-484 ). Rock View Jos, Nigeria.

Garber, J. N and Hoel, L. A., 2010. Traffic and Highway Engineering. Cengage Learning:Philadelphia, PA.

Horpibulsuk, S., Phetchuay, C and Chinkulkijniwat, A., 2012. "Soil Stabilization by calcium carbide residue and fly ash". J.Mater. Civ. Eng., 24, (2):184-193.

Joel, M and Agbede, I. O., 2011. "Mechanical-cement stabilization of laterite for use a flexible pavement material". J.Mater. Civ. Eng., 23, (2):146-152.

Joel, M and Agbede, I. O., 2010. "Cement Stabilization of Igumale Shale lime admixtures for use as flexible pavement construction material". Electronic Journal of Geotechnical Engineering, (15): 1661-1673.

Millard, R. S., 1993. Road Buildings in the Tropics. State-of-the -Art Review 9. HMSO Publication. 312.

Nigerian General Specification., 1997. Roads and Bridges Works. Federal Ministry of Works and Housing: Lagos, Nigeria.
Okafor, O. F and Okonkwo, N. U., 2009. "Effect of Rice husk Ash on some Geotechnical properties of Lateritic soil". Leonardo Electronic Journal of Practices and Technologies. 15, 67-74.

Ola, S. A., 1983. "Geotechnical properties of an Attapulgite clayshale in Northwestern Nigeria." Engineering Geology. (19): 1-13.

Ola, S. A., 1974. "Need for Estimated Cement Requirements for stabilization of Laterite Soils." Journal of Transportation Engineering, Division, ASCE, 100 (2): 379-388.

Osula, D. O. A., 1993. "Laboratory trials of soil-sodium Chloride cement stabilization for problem laterite." Journal of Transportation Engineering, ASCE, 119, (1): 149-158.

Reid, J. M and Brooks, A. H., 1999. "Investigation of Lime stabilized contaminated soils". Engineering Geology, 53, 217-231.

Somna, K., Jaturapitakkul, C and Kajitvichyanukul, P., 2011. "Microstructure of Calcium Carbide ResidueGround Fly Ash paste." J. Mater. Civ. Eng., 23, (3): 298-304.

Umar, S. Y and Elinwa, A. U., 2005. "Effects of Iron ore tallings (IOT) and Lime on Engineering Properties of problem laterite". Journal of Raw Materials Research. 2, (1): 56-66.

Umar, S. Y and Osinubi, K. J., 2003. "Stabilization Potentials of blast furnace slag(BFS) admixture on cement treated black cotton soil". NSE Technical Transactions. 37, (3): 1-13.

Yoder, E. J and Witczak, M. W., 1975. Principles of pavement Design. Wiley, New York. 